\title{
Decreased Levels of Microfibril-Associated Glycoprotein (MAGP)-1 in Patients with Colon Cancer and Obesity Are Associated with Changes in Extracellular Matrix Remodelling
}

\author{
Iranzu Gómez de Segura ${ }^{1}\left(\mathbb{D}\right.$, Patricia Ahechu ${ }^{2}$, Javier Gómez-Ambrosi 1,3,4 ${ }^{\mathbb{D}}$, Amaia Rodríguez ${ }^{1,3,4} \mathbb{C}^{1}$,

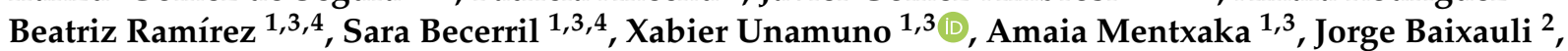 \\ Víctor Valentí ${ }^{2,3,4}$, Rafael Moncada ${ }^{3,5}$ (D), Camilo Silva ${ }^{3,4,6}$, Gema Frühbeck $1,3,4,6, *$ (I) and Victoria Catalán $1,3,4, *$ (i)
}

check for updates

Citation: Gómez de Segura, I.; Ahechu, P.; Gómez-Ambrosi, J.; Rodríguez, A.; Ramírez, B.; Becerril, S.; Unamuno, X.; Mentxaka, A.; Baixauli,

J.; Valentí, V.; et al. Decreased Levels of Microfibril-Associated Glycoprotein (MAGP)-1 in Patients with Colon Cancer and Obesity Are Associated with Changes in Extracellular Matrix Remodelling. Int. J. Mol. Sci. 2021, 22 8485. https://doi.org/10.3390/ ijms22168485

Academic Editor: Eok-Soo Oh

Received: 24 June 2021

Accepted: 3 August 2021

Published: 6 August 2021

Publisher's Note: MDPI stays neutral with regard to jurisdictional claims in published maps and institutional affiliations.

Copyright: (c) 2021 by the authors. Licensee MDPI, Basel, Switzerland. This article is an open access article distributed under the terms and conditions of the Creative Commons Attribution (CC BY) license (https:// creativecommons.org/licenses/by/ $4.0 /)$.
1 Metabolic Research Laboratory, Clínica Universidad de Navarra, 31008 Pamplona, Spain; igomezdeseg@alumni.unav.es (I.G.d.S.); jagomez@unav.es (J.G.-A.); arodmur@unav.es (A.R.); bearamirez@unav.es (B.R.); sbecman@unav.es (S.B.); xunamuno@u.es (X.U.); amentxaka@alumni.unav.es (A.M.)

2 Department of Surgery, Clínica Universidad de Navarra, 31008 Pamplona, Spain; pahechu@unav.es (P.A.); jbaixauli@unav.es (J.B.); vvalenti@unav.es (V.V.)

3 CIBEROBN, Instituto de Salud Carlos III, 31008 Pamplona, Spain; rmoncada@unav.es (R.M.); csilvafr@unav.es (C.S.)

4 Obesity and Adipobiology Group, IdiSNA, 31008 Pamplona, Spain

5 Department of Anesthesia, Clínica Universidad de Navarra, 31008 Pamplona, Spain

6 Department of Endocrinology \& Nutrition, Clínica Universidad de Navarra, 31008 Pamplona, Spain

* Correspondence: gfruhbeck@unav.es (G.F.); vcatalan@unav.es (V.C.); Tel.: +34-9-4825-5400 (ext. 4484) (G.F.); +34-9-4825-5400 (ext. 5133) (V.C.)

Abstract: Objective: The protein microfibril-associated glycoprotein (MAGP)-1 constitutes a crucial extracellular matrix protein. We aimed to determine its impact on visceral adipose tissue (VAT) remodelling during obesity-associated colon cancer (CC). Methods: Samples obtained from 79 subjects ( 29 normoponderal (NP) (17 with CC) and 50 patients with obesity (OB) (19 with CC)) were used in the study. Circulating concentrations of MAGP-1 and its gene expression levels (MFAP2) in VAT were analysed. The impact of inflammation-related factors and adipocyte-conditioned media (ACM) on MFAP2 mRNA levels in colon adenocarcinoma HT-29 cells were further analysed. The effects of MAGP-1 in the expression of genes involved in the extracellular matrix (ECM) remodelling and tumorigenesis in HT-29 cells was also explored. Results: Obesity $(p<0.01)$ and CC $(p<0.001)$ significantly decreased MFAP2 gene expression levels in VAT whereas an opposite trend in TGFB1 mRNA levels was observed. Increased mRNA levels of MFAP2 after the stimulation of HT-29 cells with lipopolysaccharide (LPS) $(p<0.01)$ and interleukin (IL)-4 $(p<0.01)$ together with a downregulation $(p<0.05)$ after hypoxia mimicked by $\mathrm{CoCl}_{2}$ treatment was observed. MAGP-1 treatment significantly enhanced the mRNA levels of the ECM-remodelling genes collagen type 6 $\alpha 3$ chain $(C O L 6 A 3)(p<0.05)$, decorin $(D C N)(p<0.01)$, osteopontin $(S P P 1)(p<0.05)$ and TGFB1 $(p<0.05)$. Furthermore, MAGP-1 significantly reduced $(p<0.05)$ the gene expression levels of prostaglandin-endoperoxide synthase 2 (COX2 / PTGS2), a key gene controlling cell proliferation, growth and adhesion in CC. Interestingly, a significant decrease $(p<0.01)$ in the mRNA levels of MFAP2 in HT-29 cells preincubated with ACM from volunteers with obesity compared with control media was observed. Conclusion: The decreased levels of MAGP-1 in patients with obesity and CC together with its capacity to modulate key genes involved in ECM remodelling and tumorigenesis suggest MAGP-1 as a link between AT excess and obesity-associated CC development.

Keywords: obesity; colon cancer; adipose tissue; inflammation; extracellular matrix remodelling; MAGP-1; TGF- $\beta$ 


\section{Introduction}

Colon cancer (CC) is the second leading cause of death in developed societies [1]. More than one-half of all causes of deaths related to cancer are attributable to modifiable risk factors including smoking, alcohol consumption, lack of physical activity and excess body weight with, specifically, $8 \%$ of all cancer deaths being associated to obesity [2]. Obesity, defined as an excess of adipose tissue (AT), is a concern worldwide due to its increased prevalence together with its well-known association with a cluster of chronic diseases including type 2 diabetes, cardiovascular diseases and cancer among others [3-6]. Moreover, obesity might result in delayed cancer diagnosis due to the hemodilution of several tumor biomarkers, technical difficulties and reduced image quality in medical imaging as well as lower participation in cancer screening programs [7]. Growing evidence indicates that obesity promotes CC not only by the tumour-promoting effects of systemically dysregulated adipokines and metabolic mediators, but also by local progression enhancement through chronic low-grade inflammation $[4,5,8,9]$ and the extracellular matrix (ECM) remodelling impairment of the AT [9-11]. In this sense, the ECM of the AT is now recognized as a dynamic regulator of cellular processes providing structural support to the surrounding cells and, thus, playing a crucial role in the biological function of different organs $[12,13]$. However, the dysfunctional AT in the obese state is associated with an increased deposition of ECM components and the activation of ECM receptor pathways promoting a dysregulation of inflammation and fibrosis processes [12] and favouring the development of CC [10].

The ECM of AT is composed of a milieu of basement membrane components, fibrillar and non-fibrillar collagens, fibronectin, microfibrils and different mechanotransduction proteins [13]. Among these components, the microfibril superstructures exhibit a significant relevance since they provide structural support and regulate the bioavailability of growth factors, particularly members of the transforming growth factor (TGF)- $\beta$ superfamily [14]. Microfibrils are formed by structural proteins named fibrillins and microfibril-associated proteins (MAGPs). An important member of the MAGP family is the microfibril-associated glycoprotein-1 (MAGP-1), a small protein of $21 \mathrm{kDa}$ constituent of most vertebrate microfibrils coded by the microfibril-associated protein 2 (MFAP2) gene and located on the human chromosome 1p31 [15,16]. MAGP-1 interacts noncovalently with fibrillin-1 and the active form of TGF- $\beta$ by its N-terminal position [17]. In this regard, MAGP-1 exhibits dual roles in AT: (i) to provide mechanical stability and limited elasticity to AT through the interaction with fibrillin-1 to form a functional fiber and (ii) to regulate crucial metabolic pathways including fibrosis, inflammation and thermogenesis by regulating the bioavailability of the active forms of TGF- $\beta$ [18-20].

MAGP-1 has been linked with complex phenotypes in multiple organ systems [18-21]. In this sense, Mfap2-deficient mice exhibited a phenotype of increased adiposity and impaired thermoregulation consistent with predisposition to metabolic dysfunction and increased TGF- $\beta$ activity [22-24]. The treatment of Mfap 2 knockout mice with antibodies neutralizing TGF- $\beta$ prevented increased adiposity, proposing its role in the regulation of TGF- $\beta$ in obesity and its associated comorbidities [17]. Thus, MAGP-1 has been suggested as a protective mechanism against the effects of metabolic stress, with a lack of MAGP-1 predisposing to metabolic dysfunction [22].

Different studies have also implicated MAGP-1 in tumour progression. In this line, MAGP-1 levels are known to be overexpressed in gastric cancer [25] and multiple myeloma [26]. The downregulation of MAGP-1 has been shown to inhibit the migration and invasion of gastric cancer cells with no impact on their capacity of proliferation [25]. Interestingly, MAGP-1 has been also implicated in the epithelial-mesenchymal transition (EMT) due to its interaction with TGF- $\beta$, SMAD2/3 and WNT/NOTCH pathways $[27,28]$. Increased levels of TGF- $\beta$ in obesity have been widely associated with inflammation and fibrosis creating a favourable microenvironment for CC development. Reportedly, an excessive production and/or activation of TGF- $\beta$ promotes CC progression and predicts adverse outcomes in patients with obesity [29]. 
To our knowledge, few studies have evaluated the role of MAGP-1 in human obesityassociated CC. Since MAGP-1 is reported as an important ECM component of the AT with a role in cancer progression, we hypothesized that dysregulated levels of MAGP-1 in obesity may function as a link between AT excess and CC development. Therefore, the aim of the present study was to investigate whether obesity can influence the circulating concentrations of MAGP- 1 and its gene expression levels in patients with CC promoting a microenvironment favourable for tumour growth. We determined the circulating concentrations as well as gene expression levels of MFAP2 and TGFB1 in the visceral AT (VAT) from patients with and without CC. To gain insight into the molecular mechanisms involved, the effect of different inflammation-related factors on the expression levels of MFAP2 and TGFB as well as in key ECM remodelling factors in colon adenocarcinoma HT-29 cells was explored. We also evaluated whether MAGP-1 itself can modulate the inflammatory response in the HT-29 cell line. Finally, the impact of the adipocyte-conditioned medium (ACM) obtained from patients with obesity on the expression of MFAP2 in HT-29 cells was further analyzed.

\section{Results}

2.1. Obesity and Colon Cancer Decrease Circulating Concentrations of MAGP-1 and Its Gene Expression Levels in VAT

Baseline characteristics of the study sample to analyse the effect of obesity and CC are shown in Table 1. As expected, patients from groups of patients with OB exhibited an increase $(p<0.001)$ in all anthropometric measurements compared to the NP volunteers but no differences were detected between patients with or without CC. Patients with CC were older $(p<0.001)$ compared to those without CC. Patients with OB and CC showed increased $(p<0.001)$ levels of CRP compared with NP and patients with OB but without CC. Moreover, fibrinogen concentrations were higher $(p<0.01)$ in patients with $\mathrm{OB}$ and CC compared with patients with OB without CC. Circulating concentrations of interleukin (IL)-6 were significantly increased due to obesity $(p=0.002)$ and CC $(p<0.001)$. We also found that obesity $(p=0.006)$ and CC ( $p=0.012)$ increased plasma levels of chitinase 3-like 1 (YKL-40), a marker that contributes to chronic inflammation and oncogenic transformation. In the same line, circulating levels of osteopontin (OPN) were upregulated $(p<0.001)$ by OB and CC. We also found that obesity increased $(p=0.038)$ plasma levels of vascular endothelial growth factor A (VEGFA). Oppositely, circulating levels of the anti-inflammatory cytokine IL-4 showed lower levels due to obesity $(p=0.038)$ and CC $(p=0.046)$ and IL-13 concentrations were reduced $(p=0.016)$ in patients with obesity, but no effect regarding the presence or not of CC was found. No differences were found in the global white blood cells count regarding obesity, but patients with CC exhibited an elevated number of leucocytes $(p<0.05)$ compared with those without CC.

Circulating MAGP-1 concentrations were reduced due to CC $(p=0.016)$ but no differences were found regarding obesity $(p=0.276)$ (Figure 1A). No significant differences were found between experimental groups in the circulating concentrations of TGF- $\beta$ (Figure 1B). Based on its relevance in obesity-associated inflammation and colon carcinogenesis, the VAT was selected to study MFAP2 and TGFB1 gene expression levels. Significant differences in MFAP2 gene expression levels were observed, being significantly decreased due to obesity $(p<0.010)$ and CC $(p<0.001)$ (Figure 1C). Oppositely, a tendency towards an increased gene expression levels of TGFB1 in the VAT from patients with OB and CC was found although differences were only significant for CC $(p<0.05)$ (Figure 1D). We also analysed the influence of $\mathrm{OB}$ and $\mathrm{CC}$ in the expression levels of the ECM remodelling factor collagen 6A3 (COL6A3) and decorin (DCN) (Supplementary Figure S1). Gene expression levels of COL6A3 were significantly increased $(p=0.019)$ in the VAT from patients with CC. Although $D C N$ expression tended to be higher due to $C C$, differences did not reach statistical significance. 
Table 1. Anthropometric and biochemical characteristics of the subjects included in the study.

\begin{tabular}{|c|c|c|c|c|c|c|c|}
\hline & \multicolumn{2}{|c|}{ Normoponderal } & \multicolumn{2}{|c|}{ Obesity } & \multirow[t]{2}{*}{$p$ ОВ } & \multirow[t]{2}{*}{$p \mathrm{CC}$} & \multirow[t]{2}{*}{$p \mathrm{OB} \times \mathrm{CC}$} \\
\hline & $\begin{array}{l}\text { Non-Colon } \\
\text { Cancer }\end{array}$ & Colon Cancer & $\begin{array}{l}\text { Non-Colon } \\
\text { Cancer }\end{array}$ & Colon Cancer & & & \\
\hline$n$ (male, female) & $12(5,7)$ & $17(8,7)$ & $31(18,13)$ & $19(14,5)$ & & & \\
\hline Age (years) & $53 \pm 2$ & $63 \pm 3$ & $55 \pm 1$ & $64 \pm 3$ & 0.518 & $<0.001$ & 0.925 \\
\hline Body weight (kg) & $62.7 \pm 1.9$ & $61.2 \pm 5.1$ & $83.2 \pm 2.0$ & $78.3 \pm 2.2$ & $<0.001$ & 0.577 & 0.320 \\
\hline Body mass index $\left(\mathrm{kg} / \mathrm{m}^{2}\right)$ & $22.7 \pm 0.9$ & $22.4 \pm 0.4$ & $30.2 \pm 0.7$ & $29.6 \pm 0.7$ & $<0.001$ & 0.109 & 0.588 \\
\hline Estimated body fat (\%) & $29.9 \pm 1.9$ & $29.2 \pm 1.5$ & $37.4 \pm 1.1$ & $33.4 \pm 1.4$ & $<0.001$ & 0.155 & 0.370 \\
\hline Waist (cm) & $83 \pm 1$ & $80 \pm 1$ & $99 \pm 2$ & $111 \pm 2$ & $<0.001$ & 0.241 & 0.180 \\
\hline Fasting glucose (mg/dL) & $102 \pm 4$ & $141 \pm 13$ & $110 \pm 5$ & $128 \pm 8$ & 0.730 & $<0.001$ & 0.143 \\
\hline Free fatty acids (mg/dL) & $12.7 \pm 1.4$ & $26.5 \pm 2.4$ & $15.4 \pm 1.2$ & $22.2 \pm 1.7$ & 0.570 & $<0.001$ & 0.064 \\
\hline Triglycerides $(\mathrm{mg} / \mathrm{dL})$ & $87 \pm 10$ & $112 \pm 11$ & $117 \pm 9$ & $121 \pm 20$ & 0.747 & 0.752 & 0.685 \\
\hline C-reactive protein $(\mathrm{mg} / \mathrm{L})$ & $0.20 \pm 0.13$ & $1.10 \pm 0.96$ & $1.17 \pm 0.08$ & $8.48 \pm 1.84^{* * *}$ & 0.008 & $<0.001$ & 0.031 \\
\hline Fibrinogen $(\mathrm{mg} / \mathrm{dL})$ & $337 \pm 27$ & $277 \pm 26$ & $300 \pm 17$ & $451 \pm 30^{* *}$ & 0.159 & 0.418 & 0.033 \\
\hline $\mathrm{IL}-4(\mathrm{pg} / \mathrm{mL})$ & $11.03 \pm 1.70$ & $9.22 \pm 0.31$ & $9.13 \pm 0.21$ & $8.64 \pm 0.17$ & 0.038 & 0.046 & 0.315 \\
\hline IL-6 $(\mathrm{pg} / \mathrm{mL})$ & $3.34 \pm 0.26$ & $4.45 \pm 0.45$ & $5.23 \pm 1.11$ & $9.26 \pm 1.34$ & 0.002 & $<0.001$ & 0.123 \\
\hline IL-13 (pg/mL) & $0.71 \pm 0.06$ & $0.79 \pm 0.09$ & $0.75 \pm 0.03$ & $0.57 \pm 0.03$ & 0.016 & 0.900 & 0.216 \\
\hline OPN (ng/mL) & $25.30 \pm 3.30$ & $38.93 \pm 4.48$ & $28.76 \pm 2.42$ & $70.15 \pm 10.13$ & $<0.001$ & $<0.001$ & 0.098 \\
\hline $\operatorname{VEGF}(\mathrm{ng} / \mathrm{mL})$ & $16.01 \pm 0.85$ & $16.31 \pm 0.70$ & $19.26 \pm 0.95$ & $18.39 \pm 1.27$ & 0.038 & 0.926 & 0.682 \\
\hline YKL-40 (ng/mL) & $27.00 \pm 2.19$ & $37.46 \pm 8.62$ & $39.20 \pm 4.17$ & $63.57 \pm 7.72$ & 0.006 & 0.012 & 0.309 \\
\hline $\mathrm{CEA}(\mathrm{ng} / \mathrm{mL})$ & $1.58 \pm 0.32$ & $2.55 \pm 0.44$ & $1.68 \pm 0.28$ & $8.41 \pm 2.60$ & 0.267 & 0.021 & 0.401 \\
\hline Leucocyte $\left(\times 10^{9} / \mathrm{L}\right)$ & $6.17 \pm 0.91$ & $8.19 \pm 1.14$ & $6.22 \pm 0.31$ & $7.73 \pm 0.83$ & 0.823 & 0.024 & 0.653 \\
\hline
\end{tabular}

Data are mean \pm SEM. CEA, carcinoembryonic antigen; CC, colon cancer; IL, interleukin; NP, normoponderal; OB, obesity, OPN, osteopontin; VEGF, vascular endothelial growth factor; YKL-40, chitinase 3-like 1. Statistical differences were analyzed by two-way ANCOVA and one-way ANCOVA followed by Tukey's post-hoc tests as appropriate. ${ }^{* *} p<0.01,{ }^{* * *} p<0.001$ vs. NP-non CC.
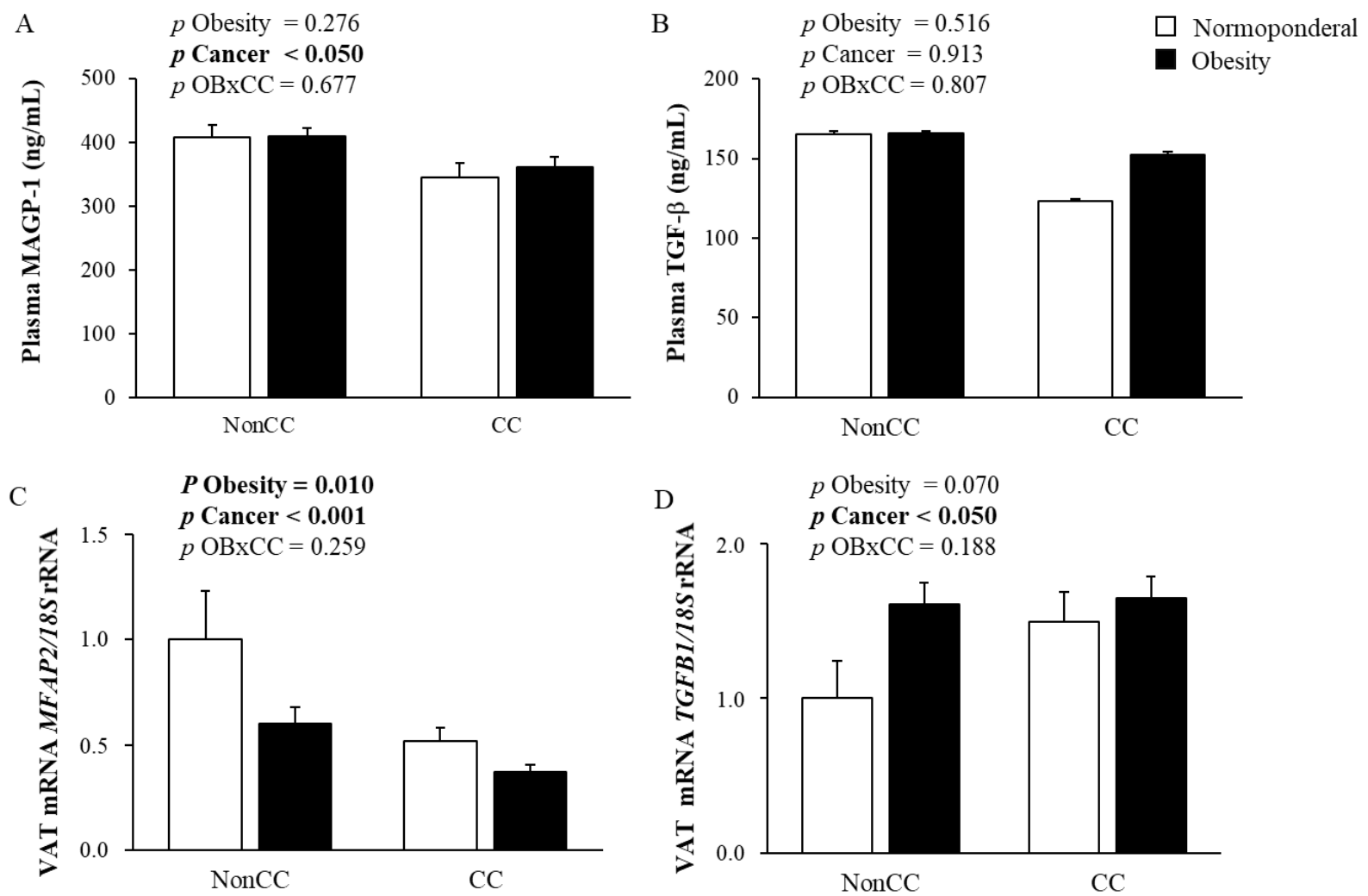

Figure 1. MAGP-1 (A) and TGF- $\beta$ (B) circulating levels in normoponderal (NP) volunteers and patients with obesity (OB) with and without colon cancer (CC). MFAP2 (C) and TGFB1 (D) gene expression levels in NP volunteers and patients with $\mathrm{OB}$ with and without CC. Differences between groups adjusted for age were analyzed by two-way ANCOVA. Bars represent the mean \pm SEM. 


\subsection{Role of Inflammation-Related Factors and Hypoxia in MFAP2 $m R N A$ Levels in Colon Adenocarcinoma HT-29 Cells}

Since it is widely recognized that chronic low-grade inflammation is a cardinal feature of CC local progression enhancement, we next evaluated whether well-known inflammation-related factors dysregulated in obesity influence MFAP2 expression in HT-29 cells. Unexpectedly, the stimulation with LPS resulted in increased $(p<0.01)$ MFAP2 gene expressions levels (Figure 2A), but no significant differences were observed on MFAP2 expression after TNF- $\alpha$ treatment (Figure 2B). Upregulated MFAP2 mRNA levels after the treatment with the anti-inflammatory factor IL-4 was found $(p<0.01)$ (Figure $2 \mathrm{C}$ ) while no significant differences after IL-13 treatment were observed (Figure 2D). HT-29 cells under hypoxia, achieved by the incubation with the divalent transition-metal ion cobalt $\left(\mathrm{CoCl}_{2}\right)$, exhibited downregulated $(p<0.05)$ MFAP2 expression levels at the higher concentration (Figure 2E). TGF- $\beta$ treatment showed an increase in the mRNA levels of $M F A P 2$, in accordance with its known binding capacity (Figure 2F).

A
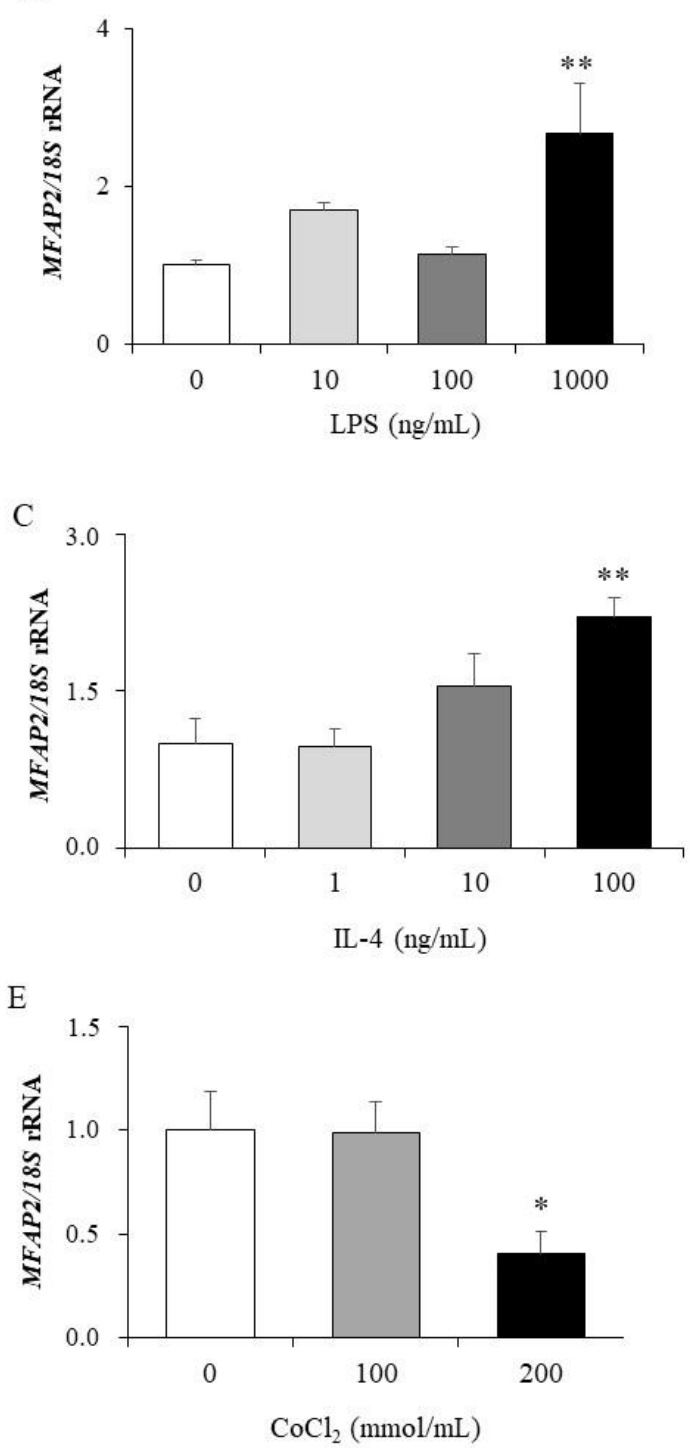
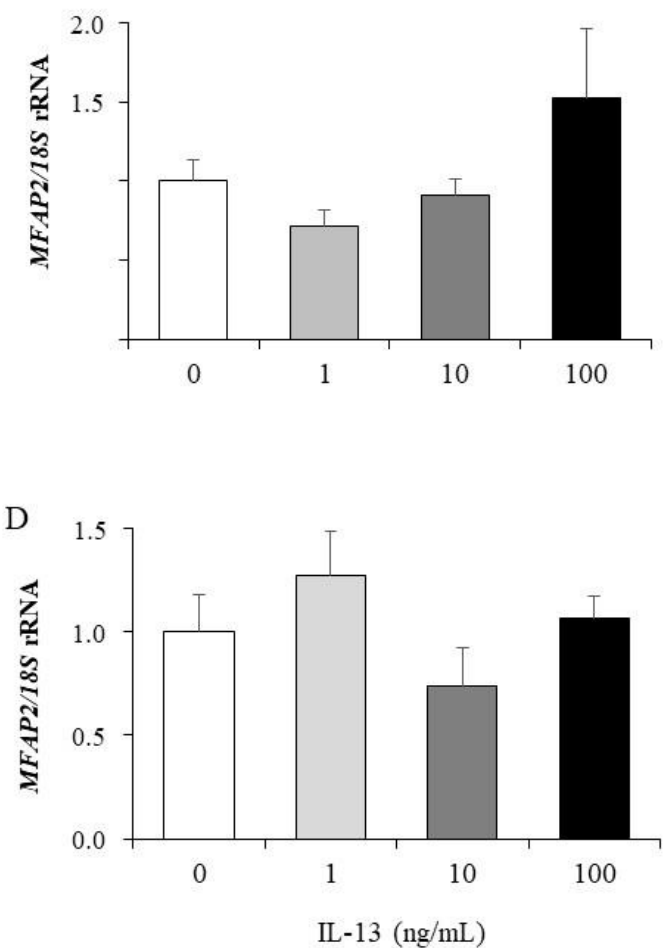

$\mathrm{F}$

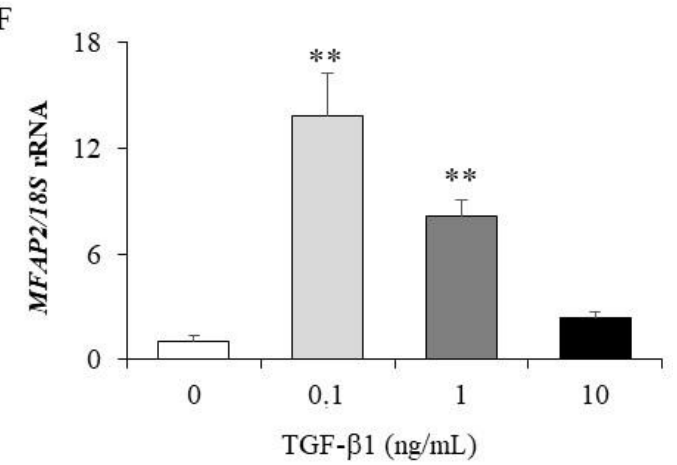

Figure 2. MFAP2 gene expression levels in HT-29 cells treated with different concentrations of LPS (A), TNF- $\alpha$ (B), IL-4 (C), IL-13, (D), $\mathrm{CoCl}_{2}$ (E) and TGF- $\beta$ (F). Gene expression levels in unstimulated cells were assumed to be 1 . Values are the mean \pm SEM ( $n=6$ per group). Differences between groups were analysed by one-way ANOVA followed by Dunnett's post-hoc tests. ${ }^{*} p<0.05,{ }^{* *} p<0.01$ vs. unstimulated cells. 
We also analyzed the effects of these inflammation-related factors in the gene expression levels of COL6A3 and DCN, two ECM proteins strongly associated with MAGP-1 (Supplementary Figure S2). No differences were found in the gene expression levels of COL6A3 and DCN after the treatment of HT-29 with LPS and TNF- $\alpha$. Although no differences were found in the mRNA levels of COL6A3 after the stimulation of HT-29 cells with the anti-inflammatory factors IL-4 and IL-13, the expression levels of DCN were significantly downregulated $(p<0.05)$ after IL-13 treatment.

\subsection{MAGP-1 Regulates the Expression of ECM- and Tumorigenesis-Related Factors in HT-29 Cells}

MAGP-1 is an important component of the ECM of AT that plays a crucial role in ECM remodelling by its binding to active TGF- $\beta$. MAGP- 1 treatment significantly enhanced the mRNA levels of the ECM-remodelling genes COL6A3 $(p<0.05), D C N(p<0.01)$, SPP1 $(p<0.05)$ and TGFB1 $(p<0.05)$ (Figure 3A,B). We also analyzed the impact of MAGP-1 on the control of the expression of specific genes regulating cell proliferation, growth and adhesion in CC. In this regard, MAGP- 1 treatment reduced $(p<0.05)$ gene expression levels of COX2. However, no significant differences in the expression levels of CTNNB1 and MUC2 were found after treatment with MAGP-1 (Figure 3B).

A

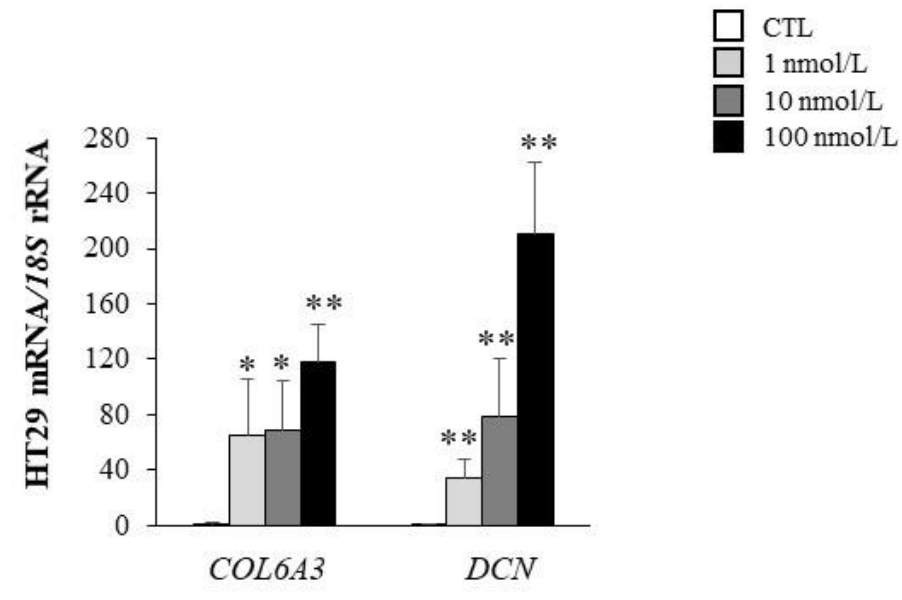

B

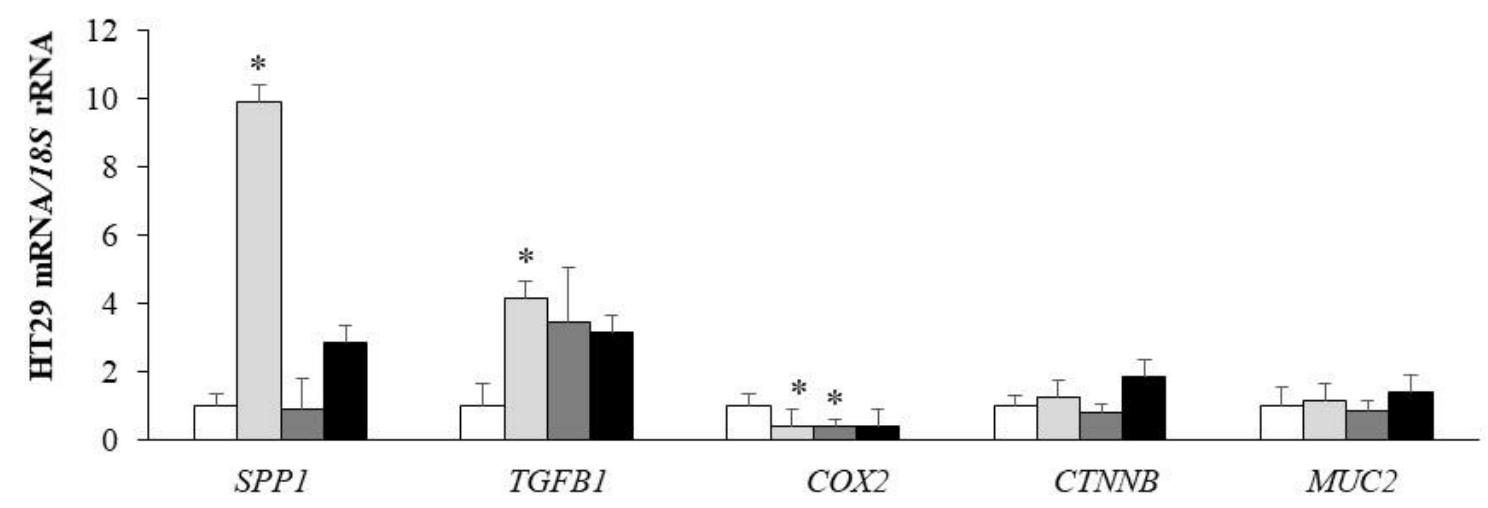

Figure 3. Gene expression levels of extracellular matrix remodelling markers (A) as well as tumorigenesis-related molecules (B) in HT-29 cells stimulated with different concentrations of recombinant MAGP-1 for $24 \mathrm{~h}$. Gene expression levels in unstimulated cells were assumed to be 1 . Values are the mean \pm SEM ( $n=6$ per group). Differences between groups were analyzed by one-way ANOVA followed by Dunnett's post-hoc tests. ${ }^{*} p<0.05$ and ${ }^{* *} p<0.01$ vs. unstimulated cells. 


\subsection{Adipocyte-Conditioned Media Downregulates Gene Expression Levels of MFAP2 in HT-29 Cells}

To gain insight into the molecular mechanisms behind the adipocyte-cancer cell crosstalk, we evaluated the effect of ACM on the mRNA levels of MFAP2 in HT-29 cells. Interestingly, we found a significant decrease $(p<0.01)$ in the expression levels of MFAP2 after incubation with the ACM obtained from volunteers with obesity (Figure 4).

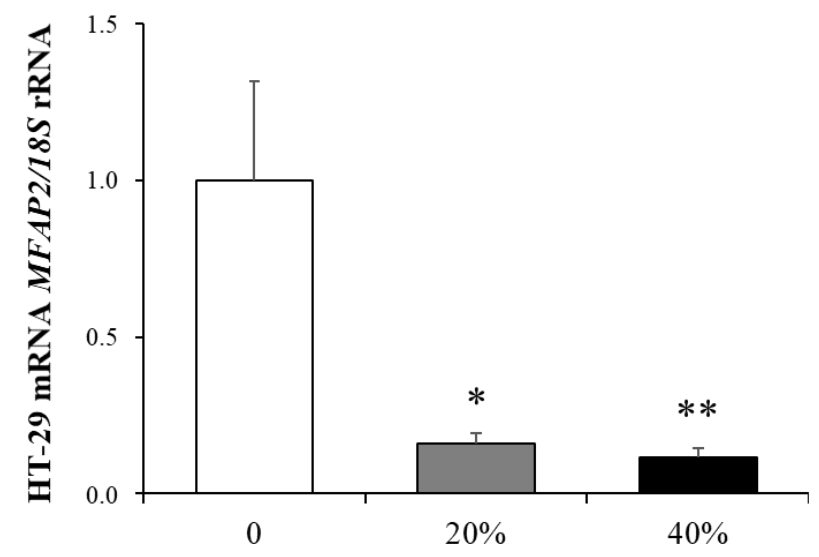

Figure 4. Bar graphs show the effect of ACM (20\% and 40\%) from obese subjects on the transcript levels of MFAP2 in HT-29 cells. Values are the mean \pm SEM ( $n=6$ per group). Differences between groups were analyzed by one-way ANOVA. ${ }^{*} p<0.05$ and ${ }^{* *} p<0.01$ vs. unstimulated cells.

\section{Discussion}

MAGP-1 constitutes a secreted signal peptide initially identified as a key component of extracellular microfibrils $[15,16]$. MAGP-1 shows a significant role in AT, protecting against obesity and metabolic dysfunction through the regulation of TGF- $\beta$ in animal models [22]. In addition, a significant involvement of MAGP-1 in tumour progression has also been demonstrated [25,26,30-32]. However, the possible role of MAGP-1 in the remodelling of the $\mathrm{AT}$ as a mechanism linking obesity and $\mathrm{CC}$ remains unclear. In this regard, the present study was designed to determine the function of MAGP-1 in obesity-associated CC. The major findings of our investigation are that: (i) obesity and CC reduce circulating and gene expression levels of MAGP-1; (ii) inflammation-related factors and hypoxia regulate MFAP2 mRNA levels in HT-29 colon cancer cells; (iii) MAGP-1 modulates the expression of ECM-related and tumorigenesis genes in HT-29 cells and (iv) the ACM obtained from patients with obesity downregulates the gene expression levels of MFAP2 in HT-29 cells.

To our knowledge, the present study is the first describing decreased circulating concentrations of MAGP-1 in patients with obesity and CC. Unexpectedly, neither obesity nor CC significantly changed circulating TGF- $\beta$ concentrations between the experimental groups. Different studies have described dysregulated MAGP-1 levels in diverse cancers underlining its implication in tumour progression, particularly in the processes of epithelial mesenchymal transition (EMT) due to its interaction with TGF- $\beta$ [27]. In this sense, opposite gene expression levels of MFAP2 have been described in different tumour types as being upregulated in gastric [25], thyroid [33] and hepatocellular [34] carcinomas and downregulated in prostate carcinoma and paragangliomas [35].

MAGP-1 transcript levels have been detected in white, beige and brown AT depots from mice with its expression levels being increased in the epididymal AT of obese mice [17]. Similarly, MFAP2 expression levels in human subcutaneous AT have been shown to be positively correlated with BMI [22]. In the present study, we report significantly decreased MFAP2 gene expression levels in the VAT due to obesity and CC together with an opposite trend in the gene expression levels of TGFB1. Considering the high affinity interaction between MAGP- 1 and TGF- $\beta$, the inverse regulation of their gene expression levels may indicate that the decreased levels of MAGP- 1 coexist with higher free active TGF- $\beta$, prompt- 
ing its interaction with the surrounding cells in the ECM of VAT. Thus, the role of MAGP-1 in inhibiting the inflammatory response may result in preventing the presence of an excessive concentration of available active TGF- $\beta$. This finding suggests that the regulation of TGF- $\beta$ by MAGP- 1 may be a protective mechanism against the effects of metabolic stress with its absence predisposing to metabolic dysfunction. As reviewed by Tan et al. [36], the excess of TGF- $\beta$ in obesity facilitates the development of metabolic syndrome by promoting inflammation and fibrosis, which impairs adipose tissue functionality by limiting adipocyte expansion. In mice, the inhibition of TGF- $\beta$ has been shown as a protective mechanism against diet-induced obesity and diabetes [37]. Moreover, VAT is considered the most pathogenic AT and the most relevant in obesity-associated inflammation and colon carcinogenesis. In this line, an excessive production and/or activation of TGF- $\beta$ promotes CC progression with TGF- $\beta$ circulating levels also predicting adverse outcomes in patients with CC [38]. Taking together, MAGP-1 and TGF- $\beta$ misbalance in the VAT from patients with obesity may participate in local inflammation and ECM remodelling, fostering obesity-related CC development. Although different tissues express and secrete MAGP-1, its decreased expression in VAT together with the reduced circulating concentration in patients with CC suggests that decreased systemic plasma levels may be in part the result of the reduced expression in VAT. In this context, obesity and CC also increased the levels of relevant inflammation and ECM remodelling factors including IL-6, OPN, YKL-40 and VEGFA. No influence of pathological features of CC in MAGP-1/MFAP2 and TGF- $\beta 1 / T G F B 1$ expression have been observed in our study. However, the extracellular expression of TGFB1 has been associated with ER-positive status $[39,40]$ being also more frequent in tumors with lymph node metastases [41]. Moreover, a different function of TGF$\beta 1$ signaling between non-metastatic and metastatic prostate cancer has been previously described [42].

Inflammation is considered a crucial factor driving carcinogenesis and, therefore, we analysed the role of the inflammation-related molecules in MFAP2 expression. In accordance with its anti-inflammatory function [43], increased levels of MFPA2 mRNA were found in HT-29 cells after IL-4 treatment. MFAP2 mRNA level upregulation may be a mechanism triggered to bind excess TGF- $\beta$ to control inflammation. In this regard, HT-29 cells under hypoxia entailed a significant downregulation of MFAP2 expression levels, pointing to hypoxia as another mechanism implicated in the regulation of MFAP2. Surprisingly, the stimulation of HT-29 cells with the well-known inflammatory factor LPS resulted in an increased MFAP2 gene expression, whereas no significant changes were observed on MFAP2 expression after TNF- $\alpha$ treatment. While LPS is a potent exogenous inflammatory factor, TNF- $\alpha$ is a less intense, intrinsic and receptor-mediated inflammatory factor. LPS-mediated inflammation pathways may be involved in MAGP-1 transduction signals, reflecting an initial compensatory protective mechanism to control increased TGF- $\beta$ levels in response to pathologic fat accumulation and its related inflammation. The treatment of HT-29 cells with TGF- $\beta$ initially increased the gene expression levels of MFAP2, but higher concentrations of TGF- $\beta$ involved a gradual downregulation in its expression levels. Given the capacity of MAGP-1 to sequester active TGF- $\beta$ in the extracellular matrix of adipose tissue, we hypothesize that MFAP2 expression levels may be upregulated as a protective response to the increased concentrations of TGF- $\beta$, with its higher concentrations exceeding the MFAP2 response capacity and inducing an exhausted compensatory mechanism.

MAGP-1 is anchored to the bead regions of fibrillin-containing microfibrils by its C-terminal domain and to surrounding matrix proteins including active forms of TGF- $\beta 1$, TGF- $\beta 2$, bone morphogenetic protein (BMP)-2, -4 and -7 [17], $\alpha 3$ chain of the collagen 6 , decorin, biglycan and fibrillin-1 [15] by its N-terminal domain. In this regard, we have established that increasing concentrations of MAGP-1 significantly enhance the gene expression levels of the ECM-remodelling genes COL6A3, SPP1 and DCN. Collagens are the most abundant proteins in the ECM. Collagen VI is a large, multidomain ECM protein composed of a triple helix of $\alpha 1, \alpha 2$, and $\alpha 3$, upregulated in different human cancers that 
also exhibits a pro-oncogenic role. COL6A3 expression has been shown to be reduced in obesity, whereas weight loss achieved by caloric restriction and surgery increased COL6A3 expression in subcutaneous AT [44]. In this sense, MAGP-1 may play a role in OBassociated CC by regulating extracellular matrix composition via COL6A3. Osteopontin, the protein codified by the SPP1 gene, is an inflammatory factor upregulated in obesity with a critical role in chronic inflammatory diseases and cancer [11]. Together with decorin, the protein codified by $D C N$, both proteins are highly involved in the tumour development process $[45,46]$. The lack of $D C N$ has been associated with the downregulation of E-cadherin and the induction of $\beta$-catenin signaling [46]; therefore, MAGP-1 may play a protective role by increasing its gene expression levels. We found a tendency towards increased MFAP2 gene expression levels after TGF- $\beta$ treatment in HT-29 cells while stimulation with MAGP-1 enhanced the gene expression levels of TGFB1. Microfibrils not only provide structural support to tissues but also control the availability of growth factors, particularly members of the TGF- $\beta$ superfamily. MAGP- 1 sequesters active TGF- $\beta$ in the ECM and can release its latent form from assembled microfibrils [17]. In this sense, the lack of MAGP-1 would lead to an increase in TGF- $\beta$ signalling due to the inability of the ECM of the AT to sequester the active form and by the enhanced accumulation of the latent form bounded to microfibrils, creating a larger pool of TGF- $\beta$ available for activation and signalling. Since MAGP- 1 sequesters active TGF- $\beta$ in the ECM, the increased levels of TGFB1 after the stimulation with MAGP-1 may constitute a compensatory mechanism with higher concentrations of MAGP-1 being able to reduce the expression of TGFB1. COX2 is commonly upregulated in diverse tumour types, including CC, promoting cell division and proliferation, apoptosis avoidance and angiogenesis [47]. Reportedly, the blockade of the cyclooxygenase (COX) enzyme with nonsteroidal anti-inflammatory drugs (NSAID) has demonstrated an inverse association with the risk of developing CC [48] and human clinical trials have suggested COX-2 selective NSAIDs as a preventive or treatment strategy of CC. In this line, we found that MAGP-1 treatment significantly reduced gene expression levels of COX2 in HT-29 cells, similarly to anti-inflammatory drugs, supporting the anti-tumoral role of MAGP-1 in CC cells. Several lines of evidence indicate that the extracellular signal-regulated kinase $1 / 2$ (ERK1/2) pathway plays an important role in CC. In this sense, Yao et al. elegantly demonstrated that MAGP-1 activates ERK1/2 through the MFAP2/integrin $\alpha 5 \beta 1 / F A K / E R K 1 / 2$ pathway in gastric cancer [32]. Moreover, another member of the microfibrillar-associated proteins, MFAP5, has also been implicated in the activation of the ERK signaling pathway in breast cancer cells [49]. In addition, MAGP-1 plays a supportive role in maintaining thermoregulation by indirectly regulating expression of the thermogenic uncoupling proteins (UCPs) $[17,22]$. In this sense, brain-derived neurotrophic factor (BDNF) also leads to the activation of brown adipose tissue thermogenesis, supporting the potential association between both factors.

The significant decrease in the mRNA levels of MFAP2 in HT-29 cells preincubated with the adipocyte-derived factors obtained from volunteers with $\mathrm{OB}$ strengthens the concept of the interaction between adipocytes and tumoral cells and the contribution of adipocytes promoting a microenvironment favourable to tumour progression probably by inducing inflammation and modifying cancer cell behaviour.

This study has some limitations. Although the number of subjects in the groups may appear somewhat limited, the detailed clinical, biochemical and metabolic characterization of our subjects has to be stressed. Patients were carefully selected to avoid confounding factors and the groups encompassed highly homogeneous patients to perform a robust analysis. The treatment of HT-29 cells with the ACM obtained from patients with obesity and CC would provide important information about the role of AT in the carcinogenesis process. Moreover, the knockdown of MAFP2 in HT-29 cells would add additional data to confirm the role of MAGP-1 in inflammation and carcinogenesis.

Taken together, the decreased levels of MAGP-1 in patients with obesity and CC as well as its capacity to modulate key genes involved in ECM remodelling and tumorigenesis suggest that MAGP-1 may be an important link between AT excess and CC development 
(Figure 5). Further studies are warranted to gain further insight into the role of MAGP-1 in the development of obesity-associated CC.

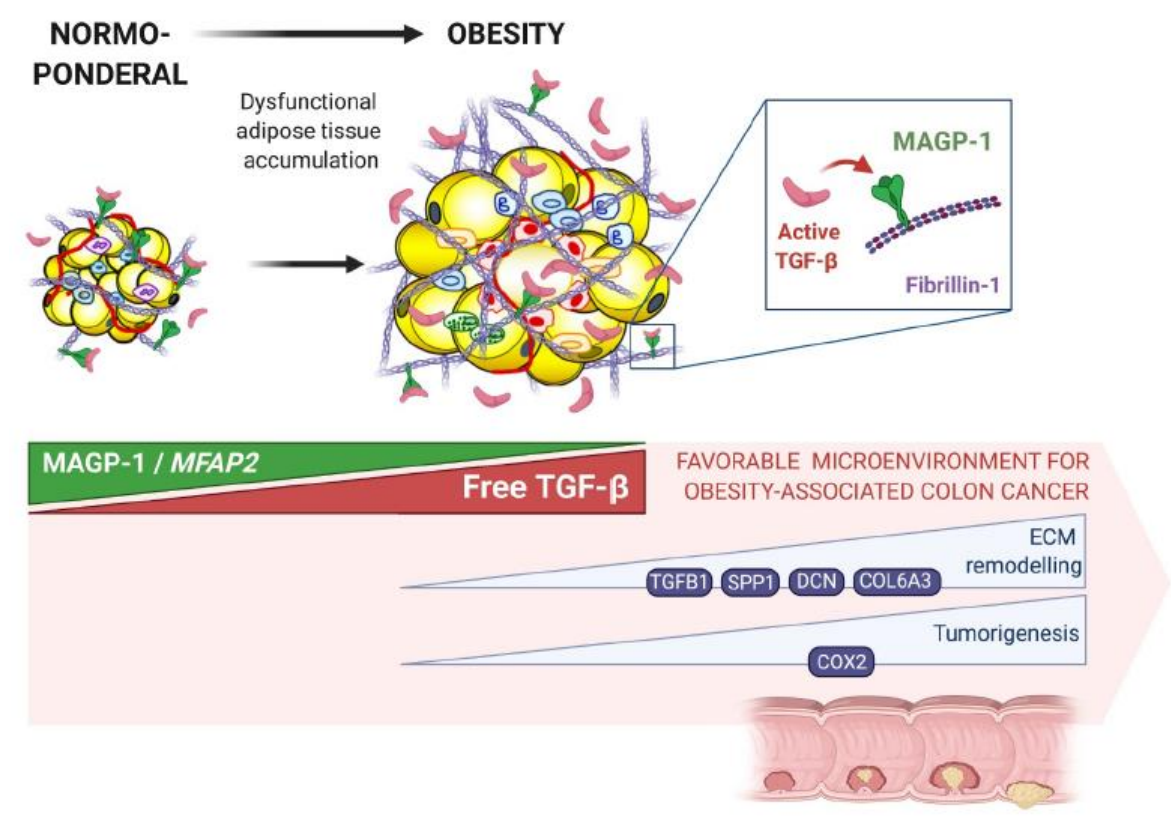

Figure 5. Proposed mechanism of the involvement of MAGP-1 in obesity-associated CC development. Decreased MFAP2 gene expression levels in the visceral adipose tissue from patients with obesity and colon cancer may be responsible for the increased free active TGF- $\beta$ enhancing its downstream signalling pathways associated with inflammation, ECM remodelling and tumorigenesis. Therefore, MAGP-1 may participate in creating a favourable microenvironment to tumorigenesis in obesity and, thus, function as a link between adipose tissue excess and obesity-associated CC development.

\section{Material and Methods}

\subsection{Patient Selection}

Tissue samples from 79 subjects ( 29 normoponderal (NP) (17 with CC) and 50 patients with obesity $(\mathrm{OB})(19$ with $\mathrm{CC})$ ) recruited from healthy volunteers and patients attending the Departments of Endocrinology \& Nutrition and Surgery at the Clínica Universidad de Navarra were used in the study. Volunteers underwent a clinical assessment including medical history, physical examination and comorbidity evaluation by a multidisciplinary team. Body mass index (BMI) was calculated as weight in kilograms divided by the square of height in meters and body fat (BF) was estimated by the CUN-BAE formula [50]. Patients were classified as NP or with OB according to BMI. Patients suffering from cancer were classified according to the established diagnostic protocol for CC. The pathological characteristics of the subjects with CC included in the study are shown in Supplementary Table S1.

VAT samples from NP volunteers were collected from Nissen fundoplication, from subjects with OB from Roux-en-Y gastric bypass (RYGB) and from patients with CC from curative resection for primary colon carcinoma at the Clínica Universidad de Navarra. The control volunteers were healthy, were not on medication and had no signs or clinical symptoms of type 2 diabetes, liver alteration or cancer. The experimental design was approved from an ethical and scientific standpoint (2018.094) for the Hospital's Ethical Committee responsible for research and all the written informed consents was obtained.

\subsection{Analytical Procedures}

Plasma samples were obtained by venipuncture after an overnight fasting. Glucose was analyzed by an automated analyzer (Hitachi Modular P800, Roche, Basel, Switzerland). Serum concentrations of triglycerides and free fatty acids (FFA) were determined by using 
commercially available kits (Infinity, Thermo Electron Corporation, Melbourne, Australia). The carcinoembryonic antigen (CEA), fibrinogen and high sensitivity C-reactive protein (CRP) concentrations were measured as previously reported [11]. White blood cell (WBC) count was determined using an automated cell counter (Beckman Coulter, Inc., Fullerton, CA, USA). Circulating levels of MAGP-1, IL-4, IL-6, IL-13, VEGFA, OPN (RayBiotech, Inc., Norcross, GA, USA) and TGF- $\beta$ (Mybiosource, San Diego, CA, USA) were assessed by commercially available ELISA kits according to the manufacturer's instructions. The intraand inter-assay coefficients of variation were $<10$ and $<12 \%$ for all analysed molecules.

\subsection{RNA Extraction and Real-Time PCR}

RNA extraction was performed by homogenization with an Ultra-Turrax T25 basic (IKA Werke Gmbh, Staugen, Germany) using QIAzol Reagent (Qiagen, Hilden, Germany) for AT and TRIzol Reagent (Invitrogen, Carlsbad, CA, USA) for HT-29 cells. All samples were treated with DNase I (RNase Free DNase set, Qiagen). Constant amounts of $2 \mu \mathrm{g}$ of total RNA were reverse transcribed in a $40 \mu \mathrm{L}$ final volume using random hexamers (Roche) as primers and 400 units of M-MLV reverse transcriptase (Invitrogen, Carlsbad, CA, USA) for cDNA synthesis.

The mRNA levels for MFAP2, TGFB1, collagen type 6 a3 chain (COL6A3), decorin $(D C N)$, secreted phosphoprotein 1 (SPP1), prostaglandin-endoperoxide synthase 2 (COX2/PTGS2), mucin 2 (MUC2) and catenin $\beta 1$ (CTNNB1) were quantified by Real-Time PCR (7300 Real Time PCR System, Applied Biosystems, Foster City, CA, USA) as previously described [10]. Primers and probes (Supplementary Table S2) were designed using the software Primer Express 2.0 (Applied Biosystems) and purchased from Genosys (Sigma-Aldrich, Madrid, Spain). Primers or TaqMan probes encompassing fragments of the areas from the extremes of two exons were designed to ensure the detection of the corresponding transcript avoiding genomic DNA amplification.

The cDNA was amplified using the TaqMan Universal PCR Master Mix (Applied Biosystems) at $95^{\circ} \mathrm{C}$ for $10 \mathrm{~min}$, followed by 45 cycles of 15 at $95^{\circ} \mathrm{C}$ and $1 \mathrm{~min}$ at $59^{\circ} \mathrm{C}$. The primer and probe concentrations were $300 \mathrm{nmol} / \mathrm{L}$ and $200 \mathrm{nmol} / \mathrm{L}$, respectively. The $18 \mathrm{~S}$ rRNA (Applied Biosystems) was the endogenous control gene for the Real-Time PCR experiments and relative quantification was calculated using the $\Delta \Delta \mathrm{Ct}$ formula [51]. Relative mRNA expression was expressed as fold expression over the calibrator sample (average of gene expression corresponding to the normoponderal group or unstimulated cells) as previously described [51]. All samples were run in duplicate, and the average values were calculated.

\subsection{Cell Cultures}

The HT-29 cell line, derived from a human colorectal adenocarcinoma, was obtained from ATCC (HTB-38TM, Middlesex, UK) and cultured according to the manufacturer's instructions. Briefly, cells were seeded at $3 \times 10^{5}$ cells/well and grown in McCoy's $5 \mathrm{~A}$ medium with L-glutamine (Sigma) supplemented with $10 \%$ fetal bovine serum and antibiotic-antimycotic at $37^{\circ} \mathrm{C}$ for $24 \mathrm{~h}$. HT-29 cells were serum-starved for $24 \mathrm{~h}$ and then incubated in the presence of tumor necrosis factor (TNF)- $\alpha(1,10$, and $100 \mathrm{ng} / \mathrm{mL})$ (Sigma), lipopolysaccharide (LPS) (10, 100 and $1000 \mathrm{ng} / \mathrm{mL}$ ) (R\&D Systems, Minneapolis, MN, USA), interleukin (IL)-4 (1, 10, and $100 \mathrm{ng} / \mathrm{mL}$ ) (R\&D Systems), IL-13 (1, 10, and $100 \mathrm{ng} / \mathrm{mL}$ ) (R\&D Systems), $\mathrm{CoCl}_{2}$ (100 and $200 \mathrm{mmol} / \mathrm{mL}$ ) (R\&D Systems), TGF- $\beta$ (0.1, 1 and $10 \mathrm{ng} / \mathrm{mL}$ ) (R\&D Systems) and adipocyte-conditioned media (ACM) (20\% and $40 \%)$ for $24 \mathrm{~h}$. In another set of experiments, cells were incubated in the presence of the recombinant form of MAGP-1 (1, 10 and $100 \mathrm{nmol} / \mathrm{mL}$ ) (R\&D Systems) for analysing the expression of related genes.

Human stromavascular fraction cells (SVFC) were isolated from VAT from patients with obesity. SVFC were seeded at $2 \times 10^{5}$ cells/well and grown in adipocyte medium [DMEM/F-12 [1:1] (Invitrogen)] supplemented with 10\% newborn calf serum (NCS). After 4 days, the medium was changed to adipocyte medium supplemented with $3 \%$ NCS, 
$0.5 \mathrm{mmol} / \mathrm{L}$ 3-isobutyl-1-methylxanthine (IBMX), $0.1 \mu \mathrm{M}$ dexamethasone, $1 \mu \mathrm{M}$ BRL49653 and $10 \mu \mathrm{g} / \mathrm{mL}$ insulin. After a 3-day induction period, cells were fed every 2 days with the same medium but without IBMX and BRL49653 supplementation for the remaining 7 days of adipocyte differentiation. The ACM was obtained from these cultures, centrifuged and diluted $(20 \%$ and $40 \%)$.

\subsection{Statistical Analysis}

Data are shown as mean \pm standard error of the mean (SEM). CRP concentrations were logarithmically transformed due to their non-normal distribution. The normal distribution of the other variables was adequate for the use of parametric tests. Differences between groups were assessed by two-way ANOVA and one-way ANOVA followed by Tukey's or Dunnett's post-hoc tests as appropriate. Differences between groups adjusted for age and gender were analyzed by analysis of covariance (ANCOVA). The calculations were performed using the SPSS/Windows version 15.0 statistical package (SPSS, Chicago, IL, USA). A $p$ value $<0.05$ was considered statistically significant.

Supplementary Materials: The following are available online at https:/ /www.mdpi.com/article/10 $.3390 /$ ijms22168485/s1.

Author Contributions: Conceptualization, I.G.d.S., G.F. and V.C.; data curation, J.G.-A., J.B. and G.F.; formal analysis, I.G.d.S., J.G.-A., A.R., B.R., S.B., A.M. and V.C.; funding acquisition, J.G.-A., G.F. and V.C.; investigation, I.G.d.S., A.R., B.R., X.U., A.M., V.V. and R.M.; methodology, P.A., A.R., B.R., X.U., J.B., V.V., R.M., C.S., G.F. and V.C.; project administration, S.B.; writing—original draft, I.G.d.S., G.F. and V.C.; writing—review \& editing, P.A., J.G.-A., A.R., B.R., S.B., X.U., A.M., J.B., V.V., R.M., C.S., G.F. and V.C. All authors have read and agreed to the published version of the manuscript.

Funding: Funded by Instituto de Salud Carlos III-FEDER (PI19/00785, PI20/00080 and PI20/00927), CIBEROBN and Spanish Association Against Cancer (AECC). Funding sources had no role in manuscript writing or the decision to submit the manuscript for publication.

Institutional Review Board Statement: The study was conducted according to the guidelines of the Declaration of Helsinki, and approved by the Clínica Universidad de Navarra's Ethical Committee (2018.094-July 2018).

Informed Consent Statement: Informed consent was obtained from all subjects involved in the study (2018.94-July 2018).

Data Availability Statement: The data presented in this study are available on request from the corresponding author upon reasonable request.

Acknowledgments: The authors gratefully acknowledge the valuable collaboration of all the members of the Multidisciplinary Obesity Team, Clínica Universidad de Navarra, Pamplona, Spain.

Conflicts of Interest: The authors have nothing to disclose.

\section{Abbreviations}

$\begin{array}{ll}\text { ACM } & \begin{array}{l}\text { adipocyte-conditioned media } \\ \text { adipose tissue }\end{array} \\ \text { AT } & \begin{array}{l}\text { body mass index } \\ \text { BMI }\end{array} \\ \text { CC } & \begin{array}{l}\text { colon cancer } \\ \text { COLlagen type } 6 \propto 3 \text { chain }\end{array} \\ \text { CTNNB1 } & \text { catenin } \beta 1 \\ \text { DCN } & \text { decorin } \\ \text { ECM } & \text { extracellular matrix } \\ \text { IL } & \text { interleukin } \\ \text { LPS } & \text { lipopolysaccharide } \\ \text { MAGP-1 } & \text { microfibril associated glycoprotein } 1 \\ \text { MUC2 } & \text { mucin } 2\end{array}$




$\begin{array}{ll}\text { NP } & \begin{array}{l}\text { Normoponderal } \\ \text { obesity }\end{array} \\ \text { CB } & \text { prostaglandin-endoperoxide synthase 2 } \\ \text { SPP1 } & \text { secreted phosphoprotein 1 } \\ \text { TGF- } \beta & \text { transforming growth factor- } \beta \\ \text { VAT } & \text { visceral adipose tissue }\end{array}$

\section{References}

1. Siegel, R.L.; Mph, K.D.M.; Jemal, A. Cancer statistics, 2019. CA Cancer J. Clin. 2018, 69, 7-34. [CrossRef]

2. Islami, F.; Sauer, A.G.; Miller, K.D.; Siegel, R.L.; Fedewa, S.A.; Jacobs, E.J.; McCullough, M.L.; Patel, A.V.; Ma, J.; Soerjomataram, I.; et al. Proportion and number of cancer cases and deaths attributable to potentially modifiable risk factors in the United States. CA Cancer J. Clin. 2017, 68, 31-54. [CrossRef]

3. Abarca-Gómez, L.; Abdeen, Z.A.; Hamid, Z.A.; Abu-Rmeileh, N.M.; Acosta-Cazares, B.; Acuin, C.; Adams, R.J.; Aekplakorn, W.; Afsana, K.; Aguilar-Salinas, C.A.; et al. Worldwide trends in body-mass index, underweight, overweight, and obesity from 1975 to 2016: A pooled analysis of 2416 population-based measurement studies in 1289 million children, adolescents, and adults. Lancet 2017, 390, 2627-2642. [CrossRef]

4. Hotamisligil, G.S. Inflammation, metaflammation and immunometabolic disorders. Nat. Cell Biol. 2017, 542, 177-185. [CrossRef]

5. Lauby-Secretan, B.; Scoccianti, C.; Loomis, D.; Grosse, Y.; Bianchini, F.; Straif, K. Body Fatness and Cancer-Viewpoint of the IARC Working Group. N. Engl. J. Med. 2016, 375, 794-798. [CrossRef] [PubMed]

6. Vecchié, A.; Dallegri, F.; Carbone, F.; Bonaventura, A.; Liberale, L.; Portincasa, P.; Frühbeck, G.; Montecucco, F. Obesity phenotypes and their paradoxical association with cardiovascular diseases. Eur. J. Intern. Med. 2018, 48, 6-17. [CrossRef]

7. Tao, W.; Lagergren, J. Clinical management of obese patients with cancer. Nat. Rev. Clin. Oncol. 2013, 10, 519-533. [CrossRef] [PubMed]

8. Kotas, M.E.; Medzhitov, R. Homeostasis, Inflammation, and Disease Susceptibility. Cell 2015, 160, 816-827. [CrossRef]

9. Crewe, C.; An, Y.A.; Scherer, P.E. The ominous triad of adipose tissue dysfunction: Inflammation, fibrosis, and impaired angiogenesis. J. Clin. Investig. 2017, 127, 74-82. [CrossRef] [PubMed]

10. Catalán, V.; Gómez-Ambrosi, J.; Rodríguez, A.; Ramírez, B.; Ortega, V.A.; Hernández-Lizoain, J.L.; Baixauli, J.; Becerril, S.; Rotellar, F.; Valentí, V.; et al. IL-32 $\alpha$-induced inflammation constitutes a link between obesity and colon cancer. OncoImmunology 2017, 6, e1328338. [CrossRef] [PubMed]

11. Catalán, V.; Gómez-Ambrosi, J.; Rodríguez, A.; Ramírez, B.; Izaguirre, M.; Hernández-Lizoain, J.L.; Baixauli, J.; Marti, P.; Valentí, V.; Moncada, R.; et al. Increased Obesity-Associated Circulating Levels of the Extracellular Matrix Proteins Osteopontin, Chitinase-3 Like-1 and Tenascin C Are Associated with Colon Cancer. PLoS ONE 2016, 11, e0162189. [CrossRef]

12. Divoux, A.; Clément, K. Architecture and the extracellular matrix: The still unappreciated components of the adipose tissue. Obes. Rev. 2011, 12, e494-e503. [CrossRef] [PubMed]

13. Mariman, E.C.M.; Wang, P. Adipocyte extracellular matrix composition, dynamics and role in obesity. Cell. Mol. Life Sci. 2010, 67, 1277-1292. [CrossRef] [PubMed]

14. Massam-Wu, T.; Chiu, M.; Choudhury, R.; Chaudhry, S.S.; Baldwin, A.; McGovern, A.; Baldock, C.; Shuttleworth, C.A.; Kielty, C.M. Assembly of fibrillin microfibrils governs extracellular deposition of latent TGF $\beta$. J. Cell Sci. 2010, 123, 3006-3018. [CrossRef]

15. Mecham, R.P.; Gibson, M.A. The microfibril-associated glycoproteins (MAGPs) and the microfibrillar niche. Matrix Biol. 2015, 47, 13-33. [CrossRef]

16. Hoffmann, K.; Mattheisen, M.; Dahm, S.; Nürnberg, P.; Roe, C.; Johnson, J.; Cox, N.J.; Wichmann, H.E.; Wienker, T.F.; Schulze, J.; et al. A German genome-wide linkage scan for type 2 diabetes supports the existence of a metabolic syndrome locus on chromosome 1p36.13 and a type 2 diabetes locus on chromosome 16p12.2. Diabetologia 2007, 50, 1418-1422. [CrossRef]

17. Craft, C.S. MAGP1, the extracellular matrix, and metabolism. Adipocyte 2014, 4, 60-64. [CrossRef]

18. Turecamo, S.; Walji, T.; Broekelmann, T.; Williams, J.; Ivanov, S.; Wee, N.; Procknow, J.; McManus, M.; Randolph, G.; Scheller, E.; et al. Contribution of metabolic disease to bone fragility in MAGP1-deficient mice. Matrix Biol. 2018, 67, 1-14. [CrossRef] [PubMed]

19. Craft, C.S.; Broekelmann, T.J.; Mecham, R.P. Microfibril-associated glycoproteins MAGP-1 and MAGP-2 in disease. Matrix Biol. 2018, 71-72, 100-110. [CrossRef]

20. Combs, M.D.; Knutsen, R.H.; Broekelmann, T.J.; Toennies, H.M.; Brett, T.J.; Miller, C.A.; Kober, D.; Craft, C.S.; Atkinson, J.J.; Shipley, J.M.; et al. Microfibril-associated Glycoprotein 2 (MAGP2) Loss of Function Has Pleiotropic Effects in vivo. J. Biol. Chem. 2013, 288, 28869-28880. [CrossRef] [PubMed]

21. Craft, C.S.; Zou, W.; Watkins, M.; Grimston, S.; Brodt, M.D.; Broekelmann, T.J.; Weinbaum, J.; Teitelbaum, S.; Pierce, R.A.; Civitelli, R.; et al. Microfibril-associated Glycoprotein-1, an Extracellular Matrix Regulator of Bone Remodeling. J. Biol. Chem. 2010, 285, 23858-23867. [CrossRef]

22. Craft, C.S.; Pietka, T.A.; Schappe, T.; Coleman, T.; Combs, M.D.; Klein, S.; Abumrad, N.A.; Mecham, R.P. The Extracellular Matrix Protein MAGP1 Supports Thermogenesis and Protects Against Obesity and Diabetes Through Regulation of TGF- $\beta$. Diabetes 2014, 63, 1920-1932. [CrossRef] [PubMed] 
23. Walji, T.A.; Turecamo, S.E.; Sanchez, A.C.; Anthony, B.A.; Abou-Ezzi, G.; Scheller, E.L.; Link, D.C.; Mecham, R.P.; Craft, C.S. Marrow Adipose Tissue Expansion Coincides with Insulin Resistance in MAGP1-Deficient Mice. Front. Endocrinol. $2016,7$. [CrossRef]

24. Levin, M.C.; Borén, J. The Extracellular Matrix Protein MAGP1 Is a Key Regulator of Adipose Tissue Remodeling During Obesity. Diabetes 2014, 63, 1858-1859. [CrossRef]

25. Wu, M.; Ding, Y.; Jiang, X.; Chen, Y.; Wu, N.; Li, L.; Wang, H.; Huang, Y.; Xu, N.; Teng, L. Overexpressed MAGP1 Is Associated With a Poor Prognosis and Promotes Cell Migration and Invasion in Gastric Cancer. Front. Oncol. 2020, 9, 1-13. [CrossRef]

26. Zaravinos, A.; Kanellou, P.; Lambrou, G.; Spandidos, D. Gene set enrichment analysis of the NF-kB/Snail/YY1/RKIP circuitry in multiple myeloma. Tumor Biol. 2014, 35, 4987-5005. [CrossRef] [PubMed]

27. Wang, J.K.; Wang, W.J.; Cai, H.Y.; Du, B.B.; Mai, P.; Zhang, L.J.; Ma, W.; Hu, Y.G.; Feng, S.F.; Miao, G.Y. MFAP2 promotes epithelial-Mesenchymal transition in gastric cancer cells by activating TGF- $\beta /$ SMAD2/ 3 signaling pathway. OncoTargets Ther. 2018, 11, 4001-4017. [CrossRef]

28. Miyamoto, A.; Lau, R.; Hein, P.W.; Shipley, J.M.; Weinmaster, G. Microfibrillar Proteins MAGP-1 and MAGP-2 Induce Notch1 Extracellular Domain Dissociation and Receptor Activation. J. Biol. Chem. 2006, 281, 10089-10097. [CrossRef]

29. Itatani, Y.; Kawada, K.; Sakai, Y. Transforming Growth Factor- $\beta$ Signaling Pathway in Colorectal Cancer and Its Tumor Microenvironment. Int. J. Mol. Sci. 2019, 20, 5822. [CrossRef] [PubMed]

30. Zhu, S.; Ye, L.; Bennett, S.; Xu, H.; He, D.; Xu, J. Molecular structure and function of microfibrillar-associated proteins in skeletal and metabolic disorders and cancers. J. Cell. Physiol. 2020, 236, 41-48. [CrossRef] [PubMed]

31. Gong, X.; Dong, T.; Niu, M.; Liang, X.; Sun, S.; Zhang, Y.; Li, Y.; Li, D. IncRNA LCPAT1 Upregulation Promotes Breast Cancer Progression via Enhancing MFAP2 Transcription. Mol. Ther. Nucleic Acids 2020, 21, 804-813. [CrossRef]

32. Yao, L.-W.; Wu, L.-L.; Zhang, L.-H.; Zhou, W.; Wu, L.; He, K.; Ren, J.-C.; Deng, Y.-C.; Yang, D.-M.; Wang, J.; et al. MFAP2 is overexpressed in gastric cancer and promotes motility via the MFAP2/integrin $\alpha 5 \beta 1 / F A K / E R K$ pathway. Oncogenesis 2020, 9 , 1-17. [CrossRef]

33. Dong, S.Y.; Chen, H.; Lin, L.Z.; Jin, L.; Chen, D.X.; Wang, O.C.; Ye, Z.Q. MFAP2 is a Potential Diagnostic and Prognostic Biomarker That Correlates with the Progression of Papillary Thyroid Cancer. Cancer Manag. Res. 2020, 12, 12557-12567. [CrossRef] [PubMed]

34. Zhu, X.; Cheng, Y.; Wu, F.; Sun, H.; Zheng, W.; Jiang, W.; Shi, J.; Ma, S.; Cao, H. MFAP2 Promotes the Proliferation of Cancer Cells and Is Associated With a Poor Prognosis in Hepatocellular Carcinoma. Technol. Cancer Res. Treat. 2020, 19, 1-14. [CrossRef]

35. Hoekstra, A.S.; Van den Ende, B.; Julià, X.P.; Van Breemen, L.; Scheurwater, K.; Tops, C.M.; Malinoc, A.; Devilee, P.; Neumann, H.P.; Bayley, J. Simple and rapid characterization of novel large germline deletions in SDHB, SDHC and SDHD-related paraganglioma. Clin. Genet. 2016, 91, 536-544. [CrossRef]

36. Tan, C.K.; Chong, H.C.; Tan, E.H.; Tan, N.S. Getting 'Smad' about obesity and diabetes. Nutr. Diabetes 2012, 2, e29. [CrossRef]

37. Yadav, H.; Quijano, C.; Kamaraju, A.K.; Gavrilova, O.; Malek, R.; Chen, W.; Zerfas, P.; Zhigang, D.; Wright, E.C.; Stuelten, C.; et al. Protection from Obesity and Diabetes by Blockade of TGF- $\beta$ /Smad3 Signaling. Cell Metab. 2011, 14, 67-79. [CrossRef]

38. Calon, A.; Lonardo, E.; Berenguer-Llergo, A.; Espinet, E.; Hernando-Momblona, X.; Iglesias, M.; Sevillano, M.; Palomo-Ponce, S.; Tauriello, D.V.F.; Byrom, D.; et al. Stromal gene expression defines poor-prognosis subtypes in colorectal cancer. Nat. Genet. 2015, 47, 320-329. [CrossRef]

39. Mu, L.; Katsaros, D.; Lu, L.; Preti, M.; Durando, A.; Arisio, R.; Yu, H. TGF- $\beta 1$ genotype and phenotype in breast cancer and their associations with IGFs and patient survival. Br. J. Cancer 2008, 99, 1357-1363. [CrossRef]

40. Figueroa, J.D.; Flanders, K.C.; Garcia-Closas, M.; Anderson, W.F.; Yang, X.R.; Matsuno, R.K.; Duggan, M.A.; Pfeiffer, R.M.; Ooshima, A.; Cornelison, R.; et al. Expression of TGF-beta signaling factors in invasive breast cancers: Relationships with age at diagnosis and tumor characteristics. Breast Cancer Res. Treat. 2009, 121, 727-735. [CrossRef]

41. Ghellal, A.; Li, C.; Hayes, M.; Byrne, G.; Bundred, N.; Kumar, S. Prognostic significance of TGF beta 1 and TGF beta 3 in human breast carcinoma. Anticancer Res. 2001, 20, 4413-4418.

42. Shiota, M.; Fujimoto, N.; Matsumoto, T.; Tsukahara, S.; Nagakawa, S.; Ueda, S.; Ushijima, M.; Kashiwagi, E.; Takeuchi, A.; Inokuchi, J.; et al. Differential Impact of TGFB1 Variation by Metastatic Status in Androgen-Deprivation Therapy for Prostate Cancer. Front. Oncol. 2021, 11, 1-7. [CrossRef]

43. Woodward, E.; Prêle, C.M.; Nicholson, S.E.; Kolesnik, T.B.; Hart, P.H. The anti-inflammatory effects of interleukin-4 are not mediated by suppressor of cytokine signalling-1 (SOCS1). Immunology 2010, 131, 118-127. [CrossRef]

44. McCulloch, L.J.; Rawling, T.J.; Sjöholm, K.; Franck, N.; Dankel, S.; Price, E.J.; Knight, B.; Liversedge, N.H.; Mellgren, G.; Nystrom, F.; et al. COL6A3 Is Regulated by Leptin in Human Adipose Tissue and Reduced in Obesity. Endocrinology 2015, 156, 134-146. [CrossRef]

45. Moorman, H.R.; Poschel, D.; Klement, J.D.; Lu, C.; Redd, P.S.; Liu, K. Osteopontin: A Key Regulator of Tumor Progression and Immunomodulation. Cancers 2020, 12, 3379. [CrossRef]

46. Mao, L.; Yang, J.; Yue, J.; Chen, Y.; Zhou, H.; Fan, D.; Zhang, Q.; Buraschi, S.; Iozzo, R.V.; Bi, X. Decorin deficiency promotes epithelial-mesenchymal transition and colon cancer metastasis. Matrix Biol. 2021, 95, 1-14. [CrossRef]

47. Voutsadakis, I.A. Pathogenesis of colorectal carcinoma and therapeutic implications: The roles of the ubiquitin?proteasome system and Cox-2. J. Cell. Mol. Med. 2007, 11, 252-285. [CrossRef]

48. Tinsley, H.; Grizzle, W.E.; Abadi, A.; Keeton, A.; Zhu, B.; Xi, Y.; Piazza, G.A. New NSAID Targets and Derivatives for Colorectal Cancer Chemoprevention. Recent Results Cancer Res. 2012, 191, 105-120. [CrossRef] 
49. Wu, Z.; Wang, T.; Fang, M.; Huang, W.; Sun, Z.; Xiao, J.; Yan, W. MFAP5 promotes tumor progression and bone metastasis by regulating ERK/MMP signaling pathways in breast cancer. Biochem. Biophys. Res. Commun. 2018, 498, 495-501. [CrossRef]

50. Gomez-Ambrosi, J.; Silva, C.; Catalan, V.; Rodríguez, A.; Galofre, J.C.; Escalada, J.; Valenti, V.; Rotellar, F.; Romero, S.; Ramírez, B.; et al. Clinical Usefulness of a New Equation for Estimating Body Fat. Diabetes Care 2011, 35, 383-388. [CrossRef] [PubMed]

51. Catalan, V.; Gomez-Ambrosi, J.; Rotellar, F.; Silva, C.; Rodríguez, A.; Salvador, J.; Gil, M.J.; Cienfuegos, J.; Frühbeck, G. Validation of Endogenous Control Genes in Human Adipose Tissue: Relevance to Obesity and Obesity-associated Type 2 Diabetes Mellitus. Horm. Metab. Res. 2007, 39, 495-500. [CrossRef] [PubMed] 